\title{
UJI AKTIVITAS ANTIOKSIDAN ALGA Halimeda opuntia DENGAN METODE DPPH [1,1-difenil-2-pikrilhidrazil]
}

\author{
Alfredo Yeheskel Kaligis ${ }^{1)}$, Adithya Yudistira ${ }^{1)}$, Henki Rotinsulu ${ }^{1)}$ \\ ${ }^{1)}$ Program Studi Farmasi FMIPA UNSRAT Manado, 95115
}

\begin{abstract}
Macroalgae genus Halimeda has potential as an antioxidant. Halimeda Opuntia is one type of green algae that is quite dominant in the waters of Lembeh Strait, Bitung. The research aims to analyse the antioxidant activity of Halimeda Opuntia. This research is an experimental laboratory with testing the ethanol extract of the Halimeda algae with the DPPH method [1,1-difenil-2-pikrilhidrazil] to analyse antioxidant activity by using Spectrophotometer. The research shows the antioxidant levels of Halimeda Opuntia algae in the waters of Lembeh Strait has antioxidant activity and the higher the concentration higher also the antioxidant levels are produced. The highest antioxidant levels are found in the Halimeda opuntia with a concentration of $100 \mathrm{mg} / \mathrm{L}$. This results show that extract of Halimeda opuntia possesses a vital potency as an antioxidant that give value added in pharmacy industries.
\end{abstract}

Keywords: Activity, Antioxidants, DPPH, Halimeda opuntia.

\begin{abstract}
ABSTRAK
Makroalga genus Halimeda terdapat potensi sebagai antioksidan. Halimeda opuntia merupakan salah satu jenis alga hijau yang cukup dominan di perairan Selat Lembeh, Bitung. Penelitian ini bertujuan untuk menganalisis aktivitas antioksidan dari Halimeda opuntia. Penelitian ini merupakan eksperimental laboratorium dengan pengujian terhadap ektrak etanol alga Halimeda opuntia dengan metode DPPH [1,1-difenil-2-pikrilhidrazil] untuk menganalisis aktivitas antioksidan dengan menggunakan spektrofotometer. Hasil penelitian ini memperlihatkan kadar antioksidan dari alga Halimeda opuntia di perairan Selat lembeh mempunyai aktivitas antioksidan dan semakin tinggi konsentrasi semakin tinggi pula kadar antioksidan yang dihasilkan. Kadar antioksidan yang paling besar terdapat pada alga Halimeda opuntia dengan konsentrasi 100mg/L. Hal ini menunjukkan bahwa ekstrak Halimeda opuntia memiliki potensi vital sebagai antioksidan yang memberikan nilai tambah dalam industri farmasi.
\end{abstract}

Kata kunci: Aktivitas, Antioksidan, DPPH, Halimeda opuntia. 


\section{PENDAHULUAN}

Laut menjanjikan potensi komersial yang sangat besar bagi bangsa Indonesia. Namun potensi tersebut akan tak berarti bila kita tidak menyadari betapa pentingnya keterlibatan teknologi untuk mengeksplorasi potensi serta sumber daya tersebut. Indonesia merupakan negara kepulauan terbesar di dunia yang terdiri dari $2 / 3$ bagiannya adalah lautan. Lautan di indonesia memiliki panjang garis pantai mencapai $95.000 \mathrm{~km}$ persegi. Ditambah lagi dengan luas hamparan terumbu karang sebesar 24,5 juta Ha. Selain dari panjang garis pantai dan luas terumbu karang, negeri Indonesia juga masih menyimpan potensi kelautan lainnya (Departemen Eksplorasi Laut dan Perikanan, 2002). Selain kelompok hewan yang hidup di laut terdapat pula kelompok tumbuhan yang disebut tumbuhan laut yang juga banyak memiliki nilai gizi dan ekonomi. Salah satu produk produk yang sudah diketahui manfaatnya adalah makro-algae laut yang dikenal dalam dunia perdagangan dengan sebutan rumput laut. Rumput laut atau lebih dikenal dengan sebutan seaweed merupakan salah satu sumber daya hayati yang sangat melimpah di perairan Indonesia yaitu sekitar 8,6\% dari total biota di laut. Luas wilayah yang menjadi habitat rumput laut di Indonesia mencapai 1,2 juta hektar atau terbesar di dunia. Potensi rumput laut perlu terus digali, mengingat tingginya keanekaragaman rumput laut di perairan Indonesia (Departemen Eksplorasi Laut dan Perikanan, 2002).

Van Bosse (melalui ekspedisi Laut Siboga pada tahun 1899-1900) melaporkan bahwa Indonesia memiliki kurang lebih 555 jenis dari 8.642 spesies rumput laut yang terdapat di dunia. Dengan kata lain, perairan Indonesia sebagai wilayah tropis memiliki sumberdaya plasma nutfah rumput laut sebesar $6,42 \%$ dari total biodiversitas rumput laut dunia. Rumput laut dari kelas alga merah (Rhodophyceae) menempati urutan terbanyak dari jumlah jenis yang tumbuh di perairan laut Indonesia yaitu sekitar 452 jenis, setelah itu alga hijau (Chlorophyceae) sekitar 196 jenis dan alga coklat (Phaeophyceae) sekitar 134. Dibalik peran ekologis dan biologisnya dalam menjaga kestabilan ekosistem laut serta sebagai tempat hidup sekaligus perlindungan bagi biota lain, golongan makroalga ini memiliki potensi ekonomis yaitu sebagai bahan baku dalam industri dan kesehatan. Dari hasil analisa terhadap sembilan jenis rumput laut menunjukkan bahwa kandungannya meliputi karbohidrat berkisar antara 39\% sampai $51 \%$, protein antara $17,2 \%$ $27,15 \%$, lemak berkisar antara $0,08 \%$ 1,9\%, vitamin A, B1, B2, B6, B12, dan C, serta meneral kalium, phospor, natrium, ferrum, dan iodium. Masyarakat wilayah pantai terutama di negara-negara Asia Pasifik telah terbiasa menjadikan rumput laut sebagai makanan. Di Jepang, lebih dari sekitar 100 jenis rumput laut telah dimanfaatkan secara tradisional sebagai makanan (Suhartono, 2000).

Antioksidan merupakan senyawa yang dapat menetralkan atau meredam radikal bebas, serta menghambat terjadinya oksidasi pada sel tubuh, sehingga dapat mencegah atau mengurangi terjadinya kerusakan sel (Abdul, 2003). Sebagai salah satu upaya untuk mengoptimalkan pemanfaatan bahan alam laut Indonesia, dilakukan penelitian dengan tujuan awal menguji aktivitas antioksidan dan mengidentifikasi senyawa berkhasiat sebagai antioksidan (Hanani $e t$ al., 2005).

Radikal bebas merupakan atom atau molekul yang memiliki satu atau lebih 
elektron yang tidak berpasangan yang dapat menarik elektron dari senyawa lain sehingga terbentuk radikal bebas antara lain dapat merusak molekul makro pembentuk sel yaitu protein, karbohidrat lemak dan deoxyribo nucleic acid (DNA) (Abdul, 2003).

Metode uji antioksidan yang digunakan pada penelitian ini adalah metode peredaman radikal bebas DPPH $(1,1-$ difenil-2-pikrilhidrazil). Metode ini memerlukan sedikit sampel, sederhana, mudah, cepat, dan peka untuk mengevaluasi aktivitas antioksidan dari senyawa bahan alam (Hanani et al., 2005).

\section{METODOLOGI PENELITIAN}

\section{Waktu dan Tempat Penelitian}

Penelitian ini dilaksanakan pada bulan Oktober 2018- Desember 2019 di Laboratorium Farmasi Lanjut Program Studi Farmasi, Fakultas Matematika dan Ilmu Pengetahuan Alam, Universitas Sam Ratulangi.

\section{Bentuk Penelitian}

Bentuk dari penelitian ini adalah eksperimental laboratorium yang akan menguji aktivitas antioksidan dengan menggunakan metode DPPH [1,1-difenil2-pikrilhidrazil] dari ekstrak alga Halimeda opuntia dari perairan Selat Lembeh.

\section{Alat}

Alat-alat yang digunakan dalam penelitian ini ialah scuba diving, labu ukur $10 \mathrm{~mL}$ (pyrex), erlenmeyer $200 \mathrm{~mL}$, cawan petri, wadah botol, spatula, gelas arloji, timbangan digital (AE ADAM), spektrofotometer UV-Vis, aluminium foil, corong, mikro pipet, tabung reaksi, dan vacum.

\section{Bahan}

Bahan yang digunakan dalam penelitian ini yaitu kertas saring, etanol 96\%, DPPH [1,1-difenil-2-pikrilhidrazil], ekstrak etanol dari alga Halimeda opuntia dan serbuk vitamin C p.a sebagai pembanding.

\section{Pengambilan Sampel}

Sampel ini diambil di perairan Selat Lembeh, Kota Bitung Provinsi Sulawesi Utara menggunakan alat bantu scuba diving. Sebelum diambil sampel di foto menggunakan kamera bawah laut, setelah diambil di masukan dalam kantong plastik jepit yang sudah di siapkan dan di simpan dalam kotak pendingin lalu di bawah ke Laboratorium Farmasi Lanjut Program Studi Farmasi Fakultas Matematika dan Ilmu Pengetahuan Alam Universitas Sam Ratulangi.

\section{Preparasi Sampel}

Alga Halimeda opuntia yang di sudah di ambil di cuci kembali dan di potongpotong kecil lalu di masukan kedalam wadah botol, sampel yang di dalam botol di isi dengan etanol 96\% sebanyak 200 $\mathrm{mL}$.

\section{Ekstraksi Sampel}

Sampel alga Halimeda opuntia sebanyak $140 \mathrm{~g}$ dimaserasi dengan pelarut etanol 96\% sebanyak $200 \mathrm{~mL}$ dengan 3 kali pengulangan selama 24 jam. Sampel kemudian disaring untuk mendapatkan filtrat. Hasil yang didapatkan kemudian diuapkan menggunakan oven sehingga menghasilkan ekstrak kental, dari sampel yang didapatkan disaring kembali untuk menghilangkan sisa garam pada ekstrak kental dengan cara ekstrak kental dilarutkan dalam etanol sebanyak $25 \mathrm{~mL}$, lalu kemudian ekrak kembali dimasukan 
ke dalam oven untuk mendapatkan ekstrak kasar dari sampel alga Halimeda opuntia.

\section{Pembuatan Larutan Stok}

Sebanyak $100 \mathrm{mg}$ ekstrak alga Halimeda opuntia dilarutkan dalam 100 $\mathrm{mL}$ etanol 96\%. Dengan masing-masing konsentrasi 25, 50, 75 dan $100 \mathrm{mg} / \mathrm{L}$, dihitung dengan menggunakan rumus pengenceran, yaitu:

$$
\mathbf{V}_{1} \cdot \mathbf{M}_{1}=\mathbf{V}_{2} \cdot \mathbf{M}_{2}
$$

Dari masing-masing hasil yang didapatkan dari hasil $\mathrm{V}_{1}$ dipipet dan ditambahkan etanol 96\% hingga mencapai tanda batas $(10 \mathrm{~mL})$, kemudian dipindahkan ke dalam tabung reaksi dan ditutup dengan menggunakan aluminium foil untuk digunakan pada perlakuan selanjutnya.

\section{Pembuatan Larutan DPPH}

Sebanyak $4 \mathrm{mg}$ DPPH ditimbang dan dilarutkan dalam etanol 96\% sebanyak 100 $\mathrm{mL}$, diencerkan menggunakan rumus pengenceran dan diuji menggunakan spektrofotometer sampai mendapatkan nilai absorbansiya.

Selanjutnya larutan yang di buat untuk uji aktivitas antioksidan yaitu ekstrak etanol alga Halimeda opuntia di pipet sebanyak $2 \mathrm{~mL}$ dimasukan kedalam tabung reaksi dengan masing-masing konsentrasi 25, 50, 75 dan $100 \mathrm{mg} / \mathrm{L}$ dan di tambahkan $2 \mathrm{~mL}$ larutan DPPH kedalam masingmasing kosentrasi dan divortex selama 5 detik sebanyak 3 kali pengulangan.

\section{Pembuatan Larutan Vitamin C}

Vitamin C p.a ditimbang sebanyak 10 mg dan dilarutkan dalam etanol $96 \%$ sebanyak $10 \mathrm{~mL}$, kemudian buat larutan stok untuk konsentrasi 25, 50, 75 dan 100 $\mathrm{mg} / \mathrm{L}$ dengan ditambahkan entanol $96 \%$ sampai tanda batas $(10 \mathrm{~mL})$ pada masing- masing larutan sebanyak 3 kali pengulangan. Sampel vitamin C p.a di pipet sebanyak $2 \mathrm{~mL}$ dimasukan kedalam tabung reaksi dengan masing-masing konsentrasi 25, 50, 75 dan $100 \mathrm{mg} / \mathrm{L}$ dan di tambahkan $2 \mathrm{~mL}$ larutan DPPH kedalam masing-masing kosentrasi dan divortex selama 5 detik sebanyak 3 kali pengulangan. diuji pada spektrofotometer UV-Vis dengan panjang gelombang 517 $\mathrm{nm}$.

\section{Pengujian Larutan Kontrol DPPH dan Aktivitas Atioksidan dengan Metode DPPH}

Larutan kontrol DPPH diuji pada spektrofotometer UV-Vis dengan panjang gelombang $517 \mathrm{~nm}$ sebagai absorbansi kontrol dalam pengujian ini. Sampel diinkubasi selama 30 menit pada suhu $37^{\circ} \mathrm{C}$. Untuk mengetahui aktivitas dari penangkal radikal bebas tersebut, di uji pada spektrofotometer. Berubahnya warna ungu menjadi warna kuning menunjukkan efisiensi penangkal radikal bebas. Diukur absorbansi pada spektrofotometer UV-Vis dengan panjang gelombang $517 \mathrm{~nm}$ setelah diinkubasi selama 30 menit berubahnya warna menjadi kuning menunjukkan bahwa, masing-masing konsentrasi menunjukkan efisiensi penangkal radikal bebas di uji dengan spektrofotometer UVVis dengan panjang gelombang $517 \mathrm{~nm}$.

Kemudian diamati perbandingannya dengan vitamin C p.a sebagai standar. Aktivitas penangkapan radikal bebas (persen inhibisi) dihitung sebagai persentase berkurangnya warna DPPH dengan menggunakan rumus:

$$
\begin{aligned}
& \% \text { inhibisi } \\
& =1-\frac{\text { absorbansi sampel }}{\text { absorbansi kontrol }} \times 100 \%
\end{aligned}
$$




\section{HASIL DAN PEMBAHASAN Hasil}

Pengujian ini dilakukan untuk mengetahui aktivitas dari penangkal radikal bebas, di uji pada spektrofotometer. Hasil pengujian disajikan pada tabel dibawah ini:

Tabel 1. Hasil perbandingan pengujian Aktivitas Antioksidan Ekstrak Etanol Alga Halimeda opuntia dengan Vitamin C p.a

\begin{tabular}{|c|c|c|c|c|c|}
\hline \multirow{2}{*}{\multicolumn{2}{|c|}{ Konsentrasi }} & \multicolumn{3}{|c|}{ Pengulangan } & \multirow{3}{*}{$\begin{array}{c}\text { Rata- } \\
\text { rata }\end{array}$} \\
\hline & & I & II & III & \\
\hline \multirow{2}{*}{$\begin{array}{l}25 \\
\%\end{array}$} & Ekstrak & $\begin{array}{c}27,80 \\
\%\end{array}$ & $\begin{array}{c}24,20 \\
\%\end{array}$ & $\begin{array}{c}25,30 \\
\%\end{array}$ & \\
\hline & $\begin{array}{c}\text { Vitamin } \\
\mathrm{C}\end{array}$ & $\begin{array}{c}93,90 \\
\%\end{array}$ & $94 \%$ & $\begin{array}{c}93,90 \\
\%\end{array}$ & $\begin{array}{c}93,90 \\
\%\end{array}$ \\
\hline \multirow{2}{*}{$\begin{array}{l}50 \\
\%\end{array}$} & Ekstrak & $\begin{array}{c}28,10 \\
\%\end{array}$ & $\begin{array}{c}25,20 \\
\%\end{array}$ & $\begin{array}{c}25,10 \\
\%\end{array}$ & $\begin{array}{c}26,10 \\
\%\end{array}$ \\
\hline & $\begin{array}{c}\text { Vitamin } \\
\mathrm{C}\end{array}$ & $\begin{array}{c}92,90 \\
\%\end{array}$ & $\begin{array}{c}93,60 \\
\%\end{array}$ & $\begin{array}{c}93,60 \\
\%\end{array}$ & $\begin{array}{c}93,30 \\
\%\end{array}$ \\
\hline \multirow{2}{*}{$\begin{array}{l}75 \\
\%\end{array}$} & Ekstrak & $\begin{array}{c}28,80 \\
\%\end{array}$ & $\begin{array}{c}27,30 \\
\%\end{array}$ & $\begin{array}{c}29,30 \\
\%\end{array}$ & $\begin{array}{c}28,40 \\
\%\end{array}$ \\
\hline & $\begin{array}{c}\text { Vitamin } \\
\mathrm{C}\end{array}$ & $\begin{array}{c}93,80 \\
\%\end{array}$ & $\begin{array}{c}93,30 \\
\%\end{array}$ & $\begin{array}{c}93,80 \\
\%\end{array}$ & $\begin{array}{c}93,60 \\
\%\end{array}$ \\
\hline \multirow{2}{*}{$\begin{array}{c}100 \\
\%\end{array}$} & Ekstrak & $\begin{array}{c}30,20 \\
\%\end{array}$ & $29 \%$ & $\begin{array}{c}30,20 \\
\%\end{array}$ & $\begin{array}{c}29,80 \\
\%\end{array}$ \\
\hline & $\begin{array}{c}\text { Vitamin } \\
\mathrm{C}\end{array}$ & $\begin{array}{c}93,90 \\
\%\end{array}$ & $\begin{array}{c}93,90 \\
\%\end{array}$ & $\begin{array}{c}93,60 \\
\%\end{array}$ & $\begin{array}{c}93,80 \\
\%\end{array}$ \\
\hline
\end{tabular}

\section{Pembahasan}

Pemanfaatan alga dalam bidang farmasi selama ini masih terbatas, sedangkan potensi alga laut di Indonesia lebih khusus di Sulawesi Utara sangat besar. Potensi alga laut Indonesia sangat besar untuk dikembangkan sebagai bahan baku obat karena mengandung senyawa bioaktif yang memiliki banyak manfaat. Salah satu contoh alga laut ialah Halimeda opuntia (Purnama et al., 2011; Widiastuti, 2003).

Penelitian ini menggunakan metode DPPH [1,1-difenil-2-pikrilhidrazil]. Ini adalah bubuk kristal berwarna gelap yang terdiri dari molekul radikal bebas yang stabil. Pengukuran antioksidan dengan metode DPPH pada prinsipnya adalah mengukur terjadinya pemudaran warna dari radikal DPPH akibat adanya antioksidan yang dapat menetralkan molekul radikal bebas. Jadi, radikal DPPH yang sebelumnya berwarna akan kehilangan warnanya jika ada antioksidan, karena antioksidan akan menyumbang elektronnya kepada radikal DPPH, sehingga radikal yang sebelumnya tidak stabil (akibat adanya elektron yang tidak berpasangan) menjadi stabil (elektron pada radikal bebas menjadi berpasangan karena mendapat sumbangan elektron dari antioksidan). Pada dasarnya, karakteristik antioksidan adalah mudah untuk menyumbangkan elektron, semakin mudah memberikan elektron maka sifat antioksidannya semakin kuat.

Sebelum melakukan pengujian DPPH dilakukan pembuatan larutan stok dimana larutan stok adalah larutan yang konsentrasinya dipekatkan atau ditinggikan dari konsentrasi media. Biasanya dinyatakan dalam kelipatan konsentrasi media dalam penelitian dilakukan pengujian dengan konsentrasi 25, 50, 75, dan $100 \mathrm{mg} / \mathrm{L}$.

Tujuan dari pembuatan larutan stok sendiri ialah untuk menghindari penimbangan yang berulang-ulang setiap kali membuat media. Dengan adanya larutan stok, pembuatan media selanjutnya tinggal mengencerkan larutan stok saja. Larutan stok dibuat hanya untuk satu jenis bahan. Langkah ini bertujuan untuk menghindari pengendapan larutan.

Sebelum larutan sampel alga Halimeda opuntia dan larutan sampel vitamin $\mathrm{C}$ p.a diuji pada alat spektrofotometer UV-Vis, kedua sampel diinkubasi terlebih dahulu dengan cara menutup sampel dengan aluminium foil selama 30 menit. 
Pengertian dari inkubasi adalah proses penjagaan atau perawatan sesuatu hal dengan kondisi tertentu agar sesuatu hal tersebut dapat berkembang dengan baik. Jadi, dalam penelitian ini, proses inkubasi sampel dimaksudkan untuk menjaga agar suhu pada sampel tetap terjaga dengan baik selama proses pengujian.

Dalam penelitian ini dibuat 3 kali pengulangan pada setiap konsentrasi yang bertujuan untuk mengetahui hasil dari masing-masing konsentrasi kemudian hasil yang didapatkan akan dihitung rataratanya, sehingga dari hasil rata-rata tersebut dapat dilihat seberapa besar aktivitas antioksidan dalam sampel alga Halimeda opuntia dibandingkan kontrol positif dari sampel vitamin C.

Hasil pengukuran aktivitas antioksidan pada larutan sampel alga Halimeda opuntia dengan konsentrasi 25, 50, 75 dan $100 \mathrm{mg} / \mathrm{L}$ menunjukkan Alga Halimeda opuntia memiliki aktivitas antioksidan dapat dilihat pada tabel 1 dengan rata-rata 25,80\% di konsentrasi $25 \mathrm{mg} / \mathrm{L}, 26,20 \%$ di konsentrasi $50 \mathrm{mg} / \mathrm{L}, \quad 28,60 \%$ di konsentrasi $75 \mathrm{mg} / \mathrm{L}$ dan konsentrasi 100 mg/L yaitu sebesar 29,80 \%. Pada jurnal Uji Aktivitas Antioksidan Dari Ekstrak Total Alga Hijau Halimeda opuntia Linnaeus dan Halimeda macroloba Decaisne Dari Perairan Teluk Totok. Meskipun alga tersebut hidup didaerah yang relatif tercemar, alga tersebut dapat berkembang dan mempunyai kandungan aktivitas antioksidan yang sangat tinggi. Dari hasil pengujian kedua ekstrak sampel Halimeda macroloba dan Halimeda opuntia memiliki kandungan antioksidan. Karena presentase nilai inhibisi dari kedua ekstrak umumnya sangat tinggi karena semakin kecil nilai absorban maka semakin tinggi nilai inhibisi dimana aktivitas antioksidan pada ekstrak semakin tinggi (Regina, 2016).

\section{KESIMPULAN}

Dari penelitian ini dapat disimpulkan bahwa ekstrak etanol Alga Halimeda opuntia yang diambil dari perairan Selat Lembeh Kota Bitung Provinsi Sulawesi Utara memiliki aktivitas antioksidan dan yang paling besar di konsentrasi $100 \mathrm{mg} / \mathrm{L}$.

\section{SARAN}

Perlu dilakukan penelitian lebih lanjut tentang alga Halimeda opuntia dengan menggunakan metode lain dan membandingkan hasilnya dengan penelitian ini.

\section{DAFTAR PUSTAKA}

Abdul, M. 2003. Peranan radikal bebas dan antioksidan dalam kesehatan dan penyakit. http://www.intisari.com/radikal.ht $\underline{\mathrm{ml}}$.

Departemen Eksplorasi Laut dan Perikanan, Program dan Kegiatan: Depatemen Eksplorasi Laut dan Perikanan Republik Indonesia tahun 2000-2004. Jakarta: Depatermen Eksplorasi Laut dan Perikanan, 2002.

Hanani, E., Mun'im, A., Sekarini, R., Wiryowidagdo, S. 2006. Uji aktivitas antioksidant beberapa spons laut dari kepulauan Seribu. Jurnal Bahan Alam Indonesia. 5 (1).

Purnama, R., Melki, Wike, A. E. P., Rozirwan. 2011. Potensi Ekstrak Rumput Laut Halimeda rencii dan Euchema cotonii sebagai Antibakteri Vibrio sp. Maspari Journal. 2: 82-88. 
Regina, L. 2016. Uji Aktivitas Antioksidan Dari Ekstrak Total Alga Hijau Halimeda opuntia Linnaeus Dan Halimeda macroloba Decaisne Dari Perairan TelukTotok, Manado. Jurnal Pesisir dan Laut Tropis. 2 (1).

Suhartono. 2000. Bioteknologi Hasil Laut. PKSPL-IPB. Edisi I. P64-70.

Widiastuti, H. N. 2003. Uji Aktivitas Metabolit Sekunder dari Rumput Laut Halimeda macroloba sebagai Senyawa Bioaktif Antijamur Candida albicans dan Torula histolutica. Jurnal Ilmu Kelautan. 8(2):114-1 